\title{
Jazz Chants Born in a Piano Bar
}

\author{
Caroline Graham \\ doi:10.7575/aiac.alls.v.1n.1p.1
}

When I first arrived in New York in the late sixties, I began teaching ESL at New York University. I didn`t really think of teaching as a profession for me. I just thought it would pay the rent so I could do what I really wanted to do which was to sing and play ragtime piano in the piano bars. When I got my first piano job in an Irish Bar it was uptown, far away from NYU so I didn`t feel it was necessary to mention this night job to my boss.

It was in that New York Irish Bar that I first got the idea for Jazz Chants so Billy Carroll`s Town Club has a very special place in my heart. I was playing and singing my old ragtime music when a friend of mine came up to me and said, "Gee it`s good to see you. You look wonderful." In those words I heard exactly the rhythm of the music I was playing. From that moment on I began to listen to the language with a new awareness and to bring my students the beat of jazz by simply tapping on my desk. It began to work very well and I could see that my students were beginning to get the sound system of spoken American English. I had decided to call it Jazz Chants and I went to my boss with an idea. I said I had found something new to do with the rhythms of American Jazz and could I have a large auditorium and invite any student who wishes to join us in the late afternoon to practice their English to Jazz. My wonderful boss, Professor Rudy Bernard, not 
only gave me the auditorium he invited five TV stations to drop in and we were on the six o'clock news that night. Jazz Chants were born!

Working in a piano bar is a whole world of its own and there are special rules for the piano player. The most important rule is you must never stop playing no matter what happens in the room. If the music stops, unless it is your regular break time people think there is trouble. You not only must keep playing but should try to play something appropriate for whatever might be going on in the room.

One night I was working in a little late night basement bar in Greenwich Village which had a large fish tank at the entrance. About three o'clock in the morning a group of teenagers appeared with hammers and began to smash the fish tank. Now the floor of the bar was covered with little goldfish swimming around. The patrons of course by this hour were quite drunk and having a fish swim by their table was not at all what they were expecting. I began to sing an old song from the 1940s called Three Little Fishies.

On another occasion a customer set fire to his paper tablecloth with one of the little candles burning at each table and I began to sing, "I don't want to set the world on fire I just want to start a flame in your heart."

Sometimes customers invite you to sit with them during your break and one night I joined a young couple who seemed to be very fond of each other. The woman told me her story. She had placed a personal ad in New York Magazine hoping to 
meet an attractive man and had received over 400 responses. She now had a different date for every night in the entire year and this man was her tenth. I played, 'If I Could Be With You One Hour Tonight'. Ah! Life in the piano bars! You never know what to expect! 